روند تغييرات صفات فيزيولوزيك ذرت متأثر از آبيارى تأخيرى و سيدروفور باكتريايى

\author{
ساناز صرافى'، آرمان آذرى ؟ّ، روحالله صابرىريسهَّ و علىاكبر محمدىميريك؟

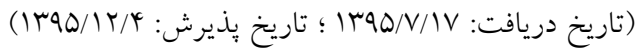

جكيده

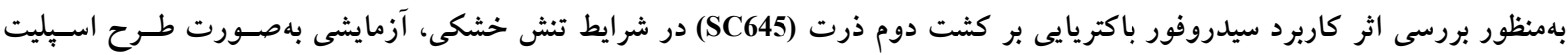

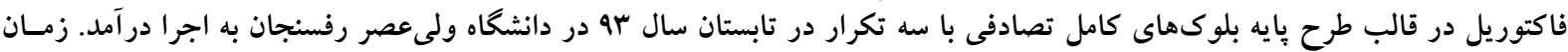

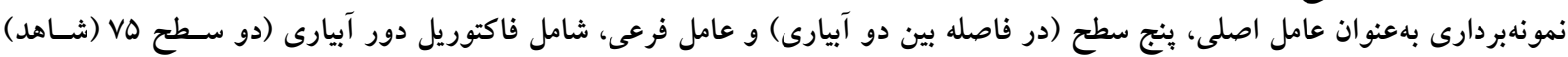

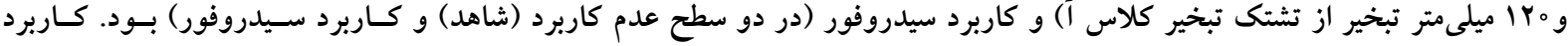

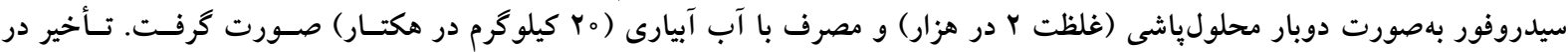

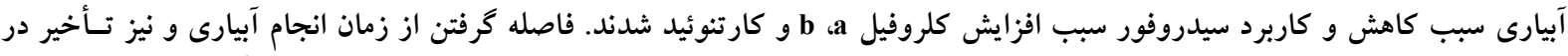

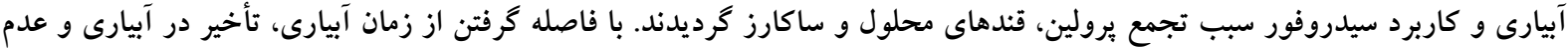

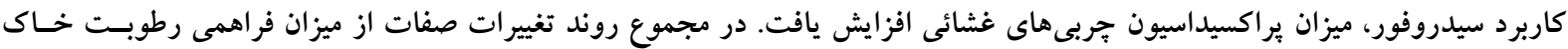

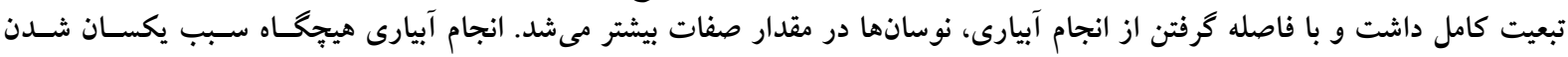

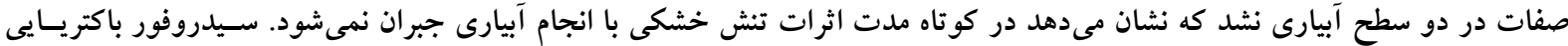

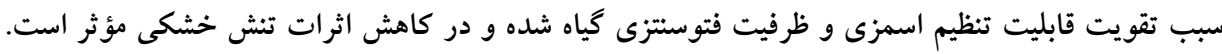

$$
\text { وازمهاى كليدى: سيدروفور، تنش خشكى، ذرت }
$$

\footnotetext{
ا و r. بهترتيب دانشجوى كارشناسى ارشد و استادياران گروه زراعت و اصلاح نباتات، دانشگاه ولىعصر (عج) رفسنجان

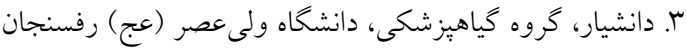

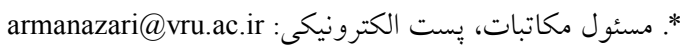


ياسخ دهل، كه از جمله اين سازو كارها تنظيم اسمزى اسـت. در

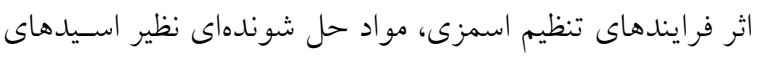

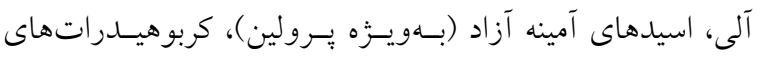
محلول و تركيبات آمونيومى نظير كليسين بتائين و آلانين بتائين إنسين

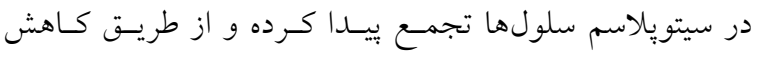

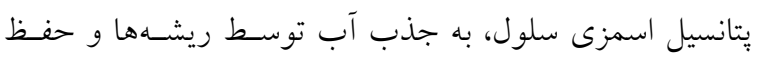

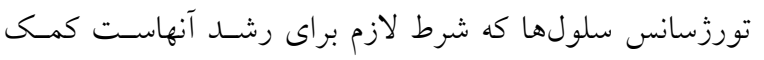

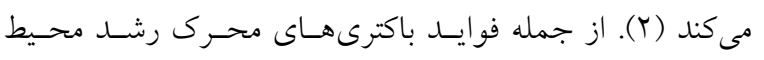

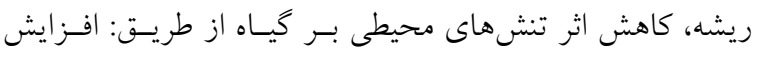

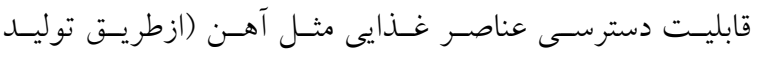

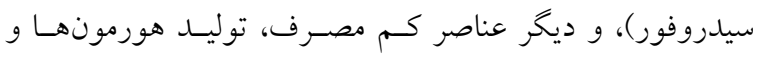
ممانعت از سنتز اتيلن (از طريـق توليــ آنـزيم -ACC دآمينـاز)

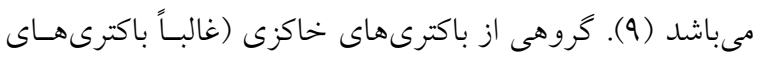
(Pseudomonas fluorescens سيدروفور (Siderophore)، تشكيل كمسبلكسهـايى بـا عناصـر

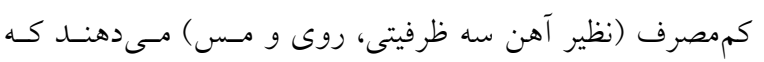

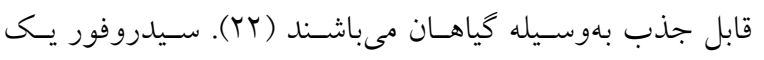
تركيب فعال كننده سيستم دفاعى منحصـر بـهفردى هسـت كـهـ وقتى روى اندامهاى هوايى كياه بِاشيده شود و يا در خاكى بهكار

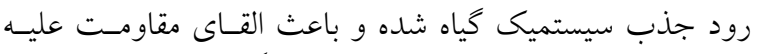

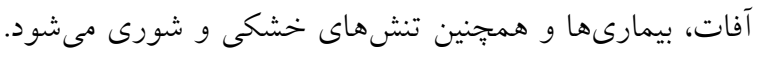

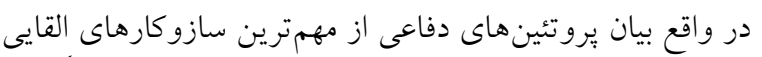

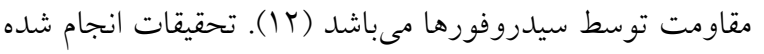

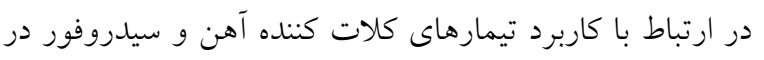

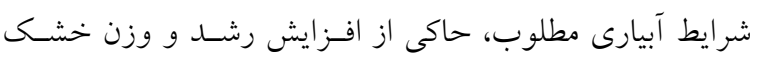
بوته و افزايش جذب آهن در ذرت بوده كه نشان از نقش مهم اين عنصر در رشد كياه دارد (آ و ب (Y). اما كاربرد سـيدروفور در شرايط كمبود رطوبت مورد بررسى قرار نخرفته است.

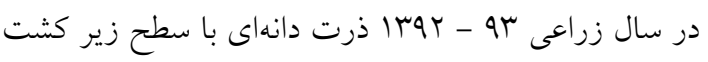

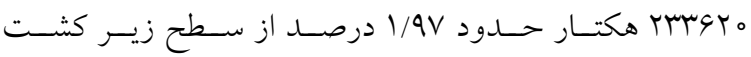
محصـولات زراعسى رادر كشـور بــه خــود اختصـاص داده و

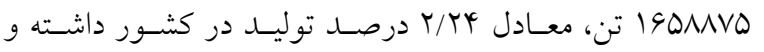

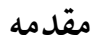

ذرت، با نام علمى Zea mays L گياهى يكساله، جهار كربنه از

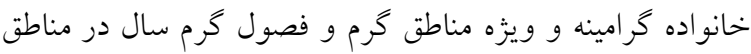

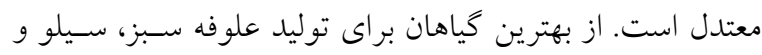

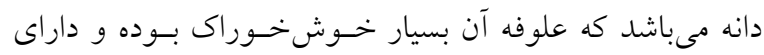

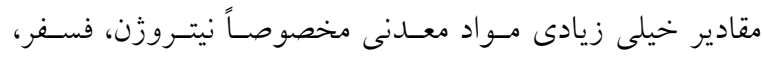
يتاسيم و كلسيم مىباشـــ ذرت احتيـاج بـه كرمـا و نسور زيـاد خورشيد داشته و مناسبترين درجه حرارت در طول دوره رشد درد

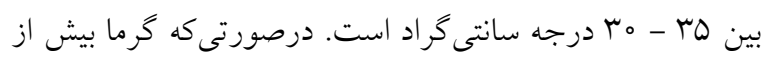

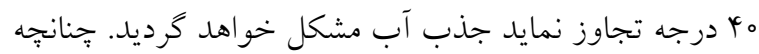

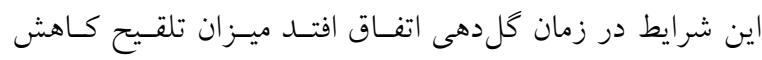

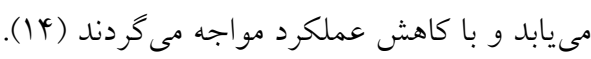

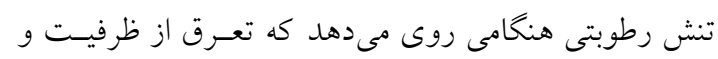

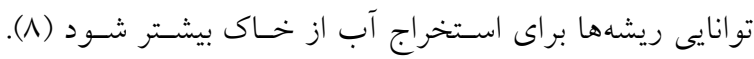

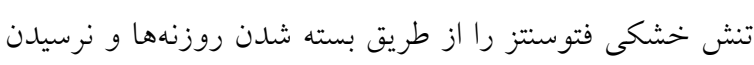

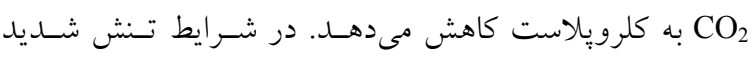

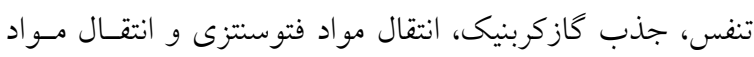
خام در آوندهاى جوبى به سرعت به حد بد بسيار كم نزول كرده و

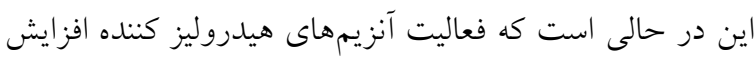

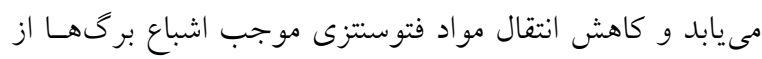

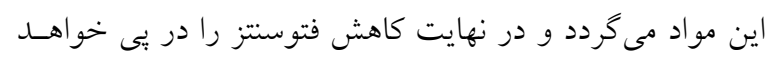

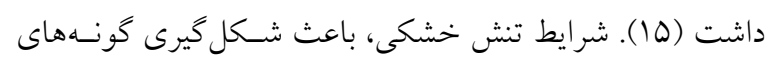

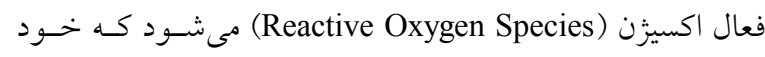
سبب بروز صدماتى مثل اكسيد شدن لييــدها و تغييـر سـاختار

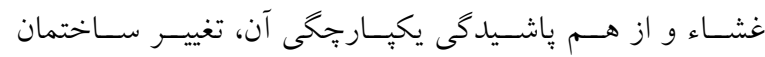

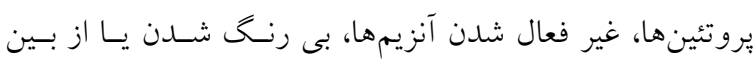
رفتن رنخدانههايى مثـل كلروفيـل و حملـه بـه فسـفوليبيدهاى

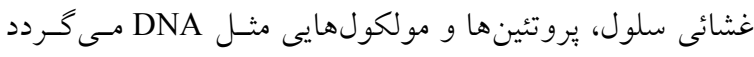

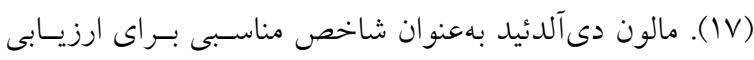

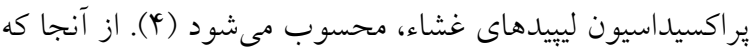

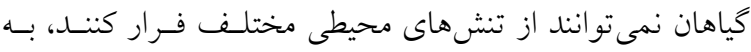

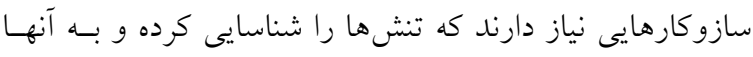


هفته پِ از آغاز گَرهبندى (به ساقه رفتن) و هـم زمـان بـا دور

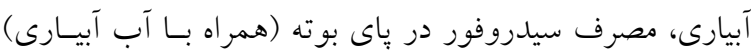

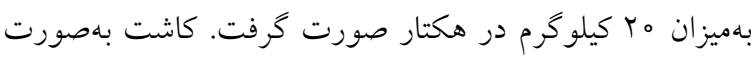

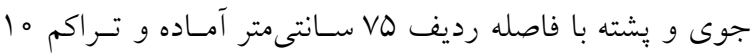

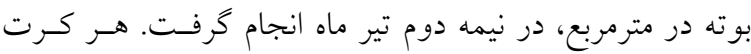

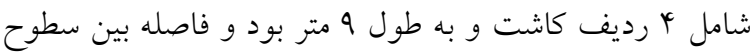

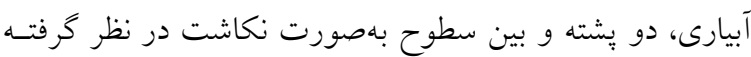

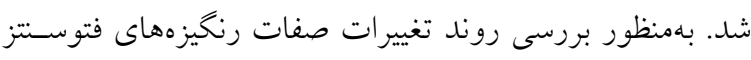

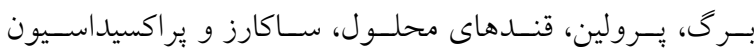

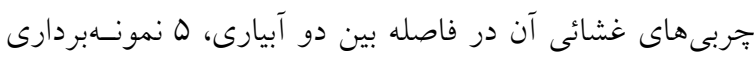

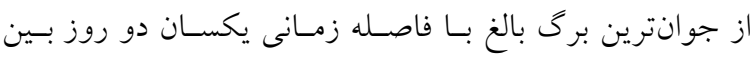

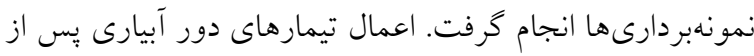

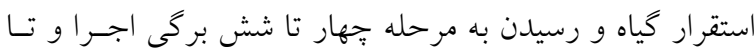

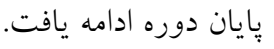

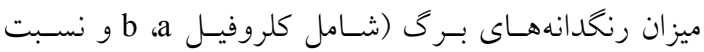

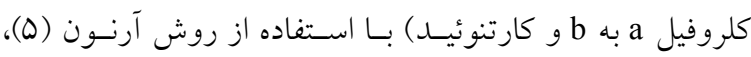

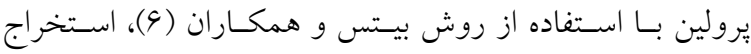

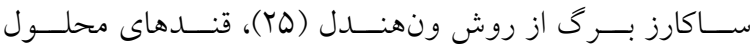
برى از روش ايريخوين و همكـاران (11) و مـالون دى آلدئيسـ بـهـعنـوان فــــاورده نهـايى (MDA: Malone Dialdehyde) ير اكسيداسيون جربى هاى غشاء از روش دى ووس و همكـاران (V) تجزيه و تحليل آمارى دادهها با استفاده از نرمافـزار SAS و و ترسيم نمودارها نيز توسط نرمافزار Excel انجام كرفت. مقايسـهـ

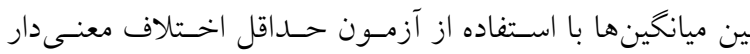
در سـطح ه درصــ (LSD: Least Significant Difference)

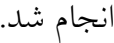

\section{نتايج و بحث رنخيزههاى برى}

اثر دور آبيارى، سيدروفور و زمان و بر همكنش سـهجانبه آنها بر محتواى رنخيزههاى برى معنى دار شد (جدول (). از بررسى
عملكردى حدود ه ها Vيلو كرم در هكتار را دارا بوده است. در

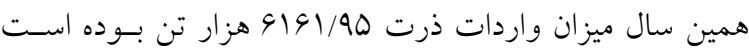

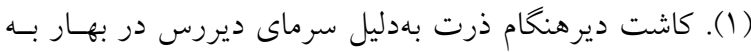

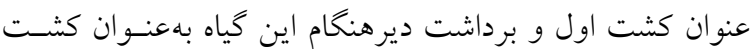

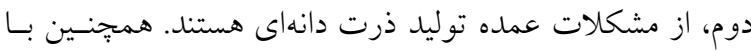

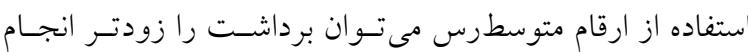

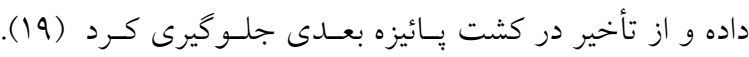

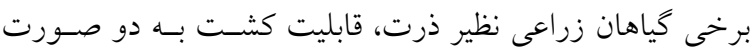
بهـاره و تابسـتانه را دارنــــ انجــام كشـت تابســانه، امكـــان

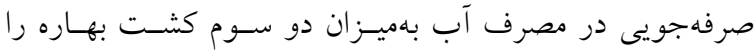

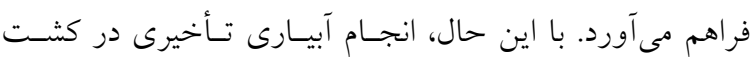

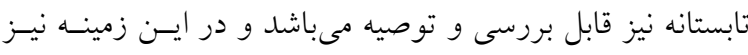
تحقيقات انجام شده بسيار محدود است (1) (1).

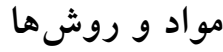
اين آزمايش با هدف بررسى اثر كاربرد بيولو گ سيدروفور (تهيه

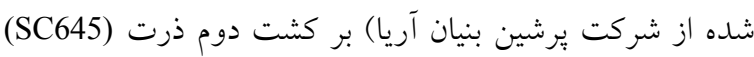

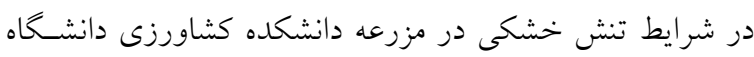

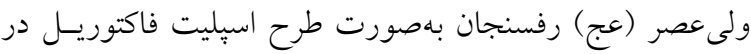

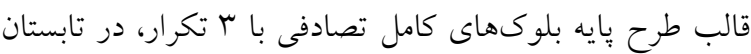

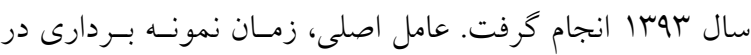

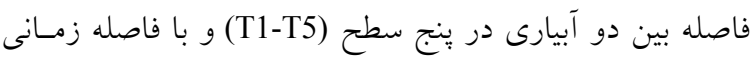

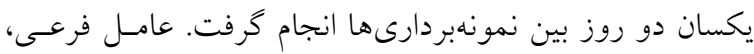

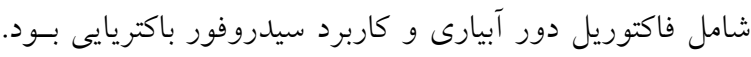

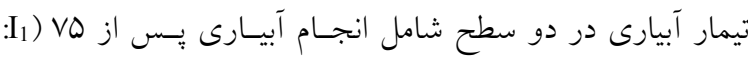

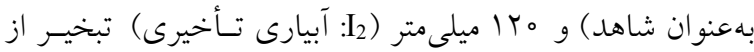
تشتك تبخير كلاس آو تيمار سـيدروفور در دو سـطح كـاربرد

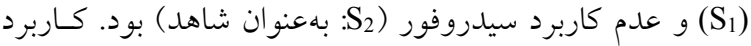
سيدروفور به دو صورت محلولياشى و مصرف بـا آب آبيـارى صورت گرفت. بدين صورت كه در دو مرحله آغاز گرمبندى و تاسل دهى محلولياشى سيدروفور با غلظت r در هزار (در تيمار

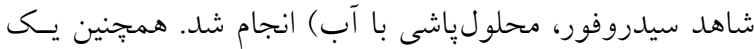




\begin{tabular}{|c|c|c|c|c|c|}
\hline كارتنوئيد & a/b كلروفيل & كلروفيل b & a كلروفيل a & درجه آزادى & منابع تغيير \\
\hline 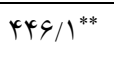 & $\circ /\left.0 \circ\right|^{\mathrm{ns}}$ & $0 /\left.01\right|^{* *}$ & ०/ Y Q ** & r & بلوى \\
\hline$\Delta Q Y I^{* *}$ & $1 / 091^{* *}$ & $0 / 19 r^{* *}$ & & 1 & دور آبيارى (I) \\
\hline 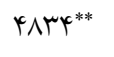 & $\circ / \mathscr{Y Y G}$ & -/ & $1 /\left.V Q\right|^{* *}$ & 1 & سيدروفور (S) \\
\hline $11 r / 1^{*}$ & $0 / 011^{\mathrm{ns}}$ & $\circ /\left.\circ \circ \circ\right|^{\mathrm{ns}}$ & $0 / 01 Y^{\mathrm{ns}}$ & 1 & $\mathrm{I} \times \mathrm{S}$ \\
\hline IN/TY & $0 / 0 T_{1}$ & $0 / 001$ & $\circ / \circ \circ \mathrm{V}$ & 4 & خطاى \\
\hline$r \circ \wedge 1^{* *}$ & $\circ / 49 \Lambda^{* *}$ & 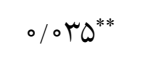 & $0 / 19 k^{* * *}$ & r & زمان (T) \\
\hline TrV/N** & $0 / 0$ Yyns & \%/००स* & $\circ / 0 \circ \varphi^{\mathrm{ns}}$ & r & $\mathrm{T} \times \mathrm{I}$ \\
\hline$r q V / \Lambda^{* *}$ & $\circ / \circ 1 Q^{\mathrm{ns}}$ & \%о०ル* & $\circ / \circ \circ Y^{n s}$ & $\varphi$ & $\mathrm{T} \times \mathrm{S}$ \\
\hline YYY/Y** & $\circ / \circ \curlyvee \Lambda^{*}$ & ०/००น* &.$/ 01 V^{* *}$ & r & $\mathrm{T} \times \mathrm{I} \times \mathrm{S}$ \\
\hline TG/To & $0 / 009$ & $0 / 001$ & ०/०० & rt & خطاى bط \\
\hline $9 / 1$ & $r / V$ & $0 / 0$ & $r / 4$ & & ضريب تغييرات (٪) \\
\hline
\end{tabular}

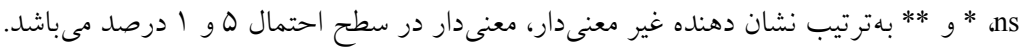

حفاظتى) دارنــد و بــه همـين دليـل تغييـرات آنهـا از شـدت و نوسانات كمترى نسبت به كلروفيل a برخوردار مىباشد. نقسش

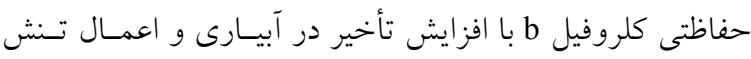
خشكى در كياه بيشتر نمود بيدا مي كند و باعث شد كـه در دور آبيارى • Y ا ميلى متر (I2)، در زمـان T4 ايسـن افـزايش مشـاهده

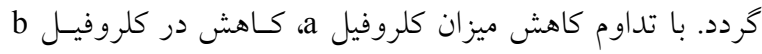
در مرحله T5 نيز انجام شد (شكل ا و ب). تحت تأثير خشكى

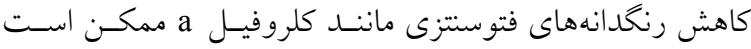
ناشى از كاهش سنتز كميلكس اصلى رنخدانه كلروفيل، تخريب

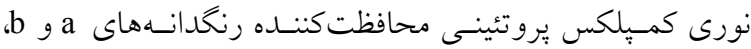
صدمه اكسيداتيو ليبيدهاى كلرويلاست و رنخدانهها و بروتئينها و يا افزايش فعاليت آنزيم كلروفيلاز باشد (YY).

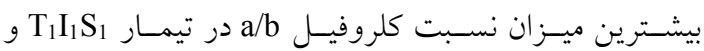
T و كمترين آن در تيمار T4 $\mathrm{T}_{1} \mathrm{~S}_{1}$ شكل r). روند تغييرات نسبت كلروفيل a/b در سطوح مختلـف آبيارى، متفاوت از همديخر بوده و تغييرات متفاوتى نشان دادند. در تيمار آبيارى II ل، در قبـل از انجـام آبيـارى، بيشـترين ميـزان نسبت كلروفيل a/b بهدست آمد كه با توجه به كـاهش ظرفيـت
همزمان جدول مقايسه ميانخينها و هم:جنين نمودارهـاى رونــ تغييرات رنخيزههاى برى (شـكلهـاى الى الى ) مطالـب زيـر برداشت مىشود:

ميزان كلروفيل a و b در دور آبيارى VD ميلىمتر تبخير (II)، همواره بيشتر از دور آبيارى تأخيرى (I2) بود. در هر دور آبيارى نيز بيشترين ميـزان كلروفيـل a و b، مربـوط بـهـ تيمـار كـاربرد سيدروفور (S1) بود. انجام آبيارى نيز باعث افزايش مقــدار ايسن دو رنخيزه نسبت به زمانهاى قبل و بعد از آبيـارى گرديسـد. بـهـ نحوى كه بيشترين ميزان كلروفيل a در تيمسار يـك روز بعـد از آبيارى، در T2 حاصل شد (جدول r T $\mathrm{T}_{1} \mathrm{I}_{2} \mathrm{~S}_{2}$ در رابطه با كلروفيل b نيز بيشترين مقـدار آن از تيمارهـاى

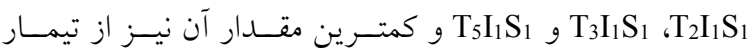
T T T $\mathrm{T}_{1} \mathrm{I}_{2} \mathrm{~S}_{2}$ واكنش تغييرات ميزان كلروفيل a نسبت به انجام آبيـارى بيشـتر از كلروفيل b صورت گرفت و اين تفاوت مربوط به وظيفه اين

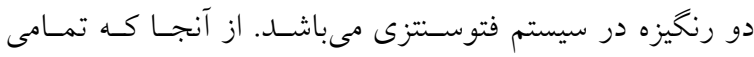
رنخيزهاى برگ به غير از كلروفيـل a نقسش كمكسى (آنستن و 
روند تغييرات صفات فيز يولوزيك ذرت متأثر از آبيارى تأخيرى و

\begin{tabular}{|c|c|c|c|c|c|c|c|c|}
\hline مالوندى آلدئيد & يرولين & كارتنوئيد & a/b كلروفيل & كلروفيل b & a كلروفيل a & \multirow[t]{2}{*}{ سيدروفور } & \multirow[t]{2}{*}{ دور آبيارى } & \multirow[t]{2}{*}{ زمان } \\
\hline $\mathrm{mmol} / \mathrm{g}$ & $\mu \mathrm{g} / \mathrm{g}$ FW & \multicolumn{4}{|c|}{$\mathrm{mg} / \mathrm{g} \mathrm{FW}$} & & & \\
\hline$r / \Lambda \circ g$ & $1 / / \Delta^{f g h i}$ & 10 cdef & $r / 0 \varphi^{a}$ & $0 / 919$ efgh & $1 / M^{c d}$ & $\mathrm{~S}_{1}$ & $\mathrm{I}_{1}$ & $\mathrm{~T}_{1}$ \\
\hline r/ore & $10 / 9^{h i}$ & $\Lambda^{\mathrm{h}}$ & $r / \Lambda \Delta^{b}$ & $\circ / 09 \circ$ ghi & $1 / 9 V^{f g}$ & $\mathrm{~S}_{2}$ & $\mathrm{I}_{1}$ & \\
\hline$c / q \circ b c$ & $r V / \Lambda^{a}$ & $\Lambda \Delta^{\mathrm{hi}}$ & $Y / V \Lambda^{\mathrm{bc}}$ & -/QGYhi & $1 / \Delta V^{g h i}$ & $\mathrm{~S}_{1}$ & $\mathrm{I}_{2}$ & \\
\hline $0 / 90^{a}$ & $1 N / Q^{c d}$ & $v^{j}$ & $r / \Delta)^{C d e f}$ & $0 / \mathbb{A}^{4} \mathrm{rj}$ & $1 / I V^{1}$ & $\mathrm{~S}_{2}$ & $\mathrm{I}_{2}$ & \\
\hline $1 /\left.9\right|^{\mathrm{h}}$ & $1 \circ / V^{i}$ & lera & $r / 9 q^{b c d}$ & o/Akoa & r/rga & $\mathrm{S}_{1}$ & $\mathrm{I}_{1}$ & $\mathrm{~T}_{2}$ \\
\hline$r / r T_{f}^{f}$ & $V / \Delta^{j}$ & $1 Y q b c$ & r/9 / cde & $. / 99 . b c d$ & $1 / 1 \mathrm{de}^{-}$ & $\mathrm{S}_{2}$ & $\mathrm{I}_{1}$ & \\
\hline$\varphi / \Delta \Delta^{c d}$ & $19 / \pi^{\mathrm{de}}$ & $|r|^{\mathrm{c}}$ & $\mathrm{T} / \mathrm{VVbc}$ & $0 / 9 Y_{0} \operatorname{defg}$ & $1 / V \Lambda^{\mathrm{de}}$ & $\mathrm{S}_{1}$ & $\mathrm{I}_{2}$ & \\
\hline $0 / 01^{b}$ & $14 / v^{e f}$ & $V \Lambda^{\mathrm{ij}}$ & T/Vobcd & $\circ / \Delta \Delta \circ^{\mathrm{i}}$ & $1 / 4 \Lambda^{\mathrm{ij}}$ & $\mathrm{S}_{2}$ & $\mathrm{I}_{2}$ & \\
\hline$r / \mathcal{G} V g$ & $14 /\left.\right|^{\mathrm{efg}}$ & $1 \circ \mathrm{Vde}$ & T/99cd & o/A०oa & $r / l Y^{b}$ & $\mathrm{~S}_{1}$ & $\mathrm{I}_{1}$ & $\mathrm{~T}_{3}$ \\
\hline$\varphi / l Y^{\mathrm{e}}$ & $|r /|_{\text {fghi }}$ & $V_{0} j$ & $T / \ll \varphi$ efg & $\circ / 9 \wedge \circ \mathrm{bcd}$ & $1 / 9 V^{f g}$ & $\mathrm{~S}_{2}$ & $\mathrm{I}_{1}$ & \\
\hline$\varphi / T y^{\text {de }}$ & $\Lambda / Q^{c d}$ & $1 \circ \wedge^{d}$ & $T / \Delta)^{\text {def }}$ & $0 / 90 r^{c d e f}$ & $1 / 90^{\mathrm{fg}}$ & $\mathrm{S}_{1}$ & $\mathrm{I}_{2}$ & \\
\hline$\varphi / q V^{b}$ & $1 \% / v^{\text {efgh }}$ & $q \wedge^{\text {efg }}$ & T/KG efg & -/D94hi & $1 / \varphi_{\circ} j$ & $\mathrm{~S}_{2}$ & $\mathrm{I}_{2}$ & \\
\hline$\bullet / \wedge \Delta^{j}$ & $11 / 0^{\text {ghi }}$ & brab & $r / r_{\circ} a$ & $\circ / \mathrm{V} / \mathrm{r}^{\mathrm{b}}$ & $r / r q^{a}$ & $\mathrm{~S}_{1}$ & $\mathrm{I}_{1}$ & ${ }^{*} \mathrm{~T}_{4}$ \\
\hline$Y / \circ V^{i j}$ & $\mid r / /^{\text {fghi }}$ & $10 r^{\mathrm{def}}$ & $T / V Q^{b c}$ & $\circ / N \circ c^{b c}$ & $1 / 9 q^{c c}$ & $\mathrm{~S}_{2}$ & $\mathrm{I}_{1}$ & \\
\hline$r /\left.\Delta\right|^{f}$ & $r N / Y^{a a}$ & $9 \Delta^{\mathrm{fgh}}$ & T/mrgh & $\circ / \mathrm{V} \circ \circ \mathrm{bc}$ & $1 / 9 \mu^{\mathrm{fgh}}$ & $\mathrm{S}_{1}$ & $\mathrm{I}_{2}$ & \\
\hline$r / q V^{e}$ & $r \circ / T^{b c}$ & $\wedge 9^{\mathrm{gh}}$ & $T / \backslash Q^{\mathrm{i}}$ & $0 / 900$ fghi & $1 / T q^{k}$ & $\mathrm{~S}_{2}$ & $\mathrm{I}_{2}$ & \\
\hline $1 / T y^{\mathrm{i}}$ & $14 /$ refg & 104 def & $r / 9 \Lambda^{\text {bcd }}$ & $\circ / V q_{\circ}{ }^{a}$ & $r / T Y^{b}$ & $\mathrm{~S}_{1}$ & $\mathrm{I}_{1}$ & $\mathrm{~T}_{5}$ \\
\hline$r / \circ \Lambda^{h}$ & $I T / N^{\text {fghi }}$ & $9 \wedge^{\text {efg }}$ & $r /\left.9\right|^{\text {cde }}$ & - /904cde & $I / V Y^{\mathrm{ef}}$ & $\mathrm{S}_{2}$ & $\mathrm{I}_{1}$ & \\
\hline $0 / 1 r^{\mathrm{b}}$ & $r q / q^{a}$ & $V Y^{j}$ & $\Gamma / \Lambda^{\mathrm{fgh}}$ & $0 / 9 \Delta \mathrm{r}^{\mathrm{cdef}}$ & $1 / \Delta$ rhi $^{-}$ & $\mathrm{S}_{1}$ & $\mathrm{I}_{2}$ & \\
\hline$\Delta / \wedge V^{\mathrm{a}}$ & $r I / V^{b}$ & $V_{0} j$ & $r / r \Delta^{h i}$ & $\circ / 09_{0} \mathrm{i}$ & $1 / T \xi^{\mathrm{k}}$ & $\mathrm{S}_{2}$ & $\mathrm{I}_{2}$ & \\
\hline$\circ / \circ \wedge$ & $r / 9 \Lambda$ & $9 / \circ$ & $\circ / I V$ & $\circ / 0 \Delta 9$ & $\circ / 10$ & & & LSD $5 \%$ \\
\hline
\end{tabular}

ميانخين هاى داراى يك حرف مشترى در هرستون، فاقد تفاوت آمارى معنىدار براساس آزمون LSD در سطح ه٪ مىباشند. "“براى دور آبيارى

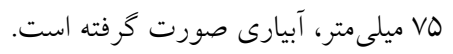

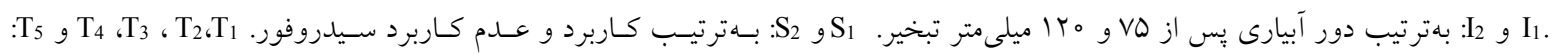

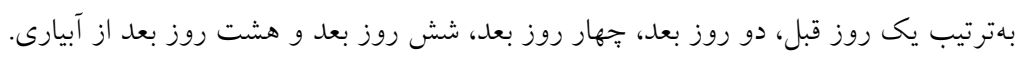

فتوسنتزى بهدليل كاهش رطوبت قابل اسـتفاده خـاك، نيـاز بـهـ كرديده اين نسبت كاهش يابد. روند كاهش تا روز سوم بعـد از

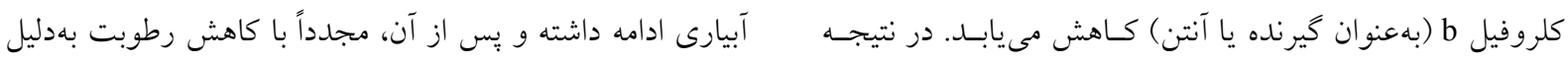

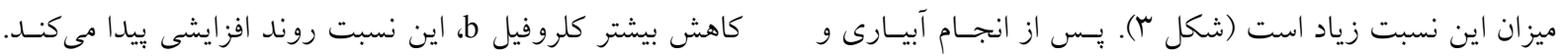

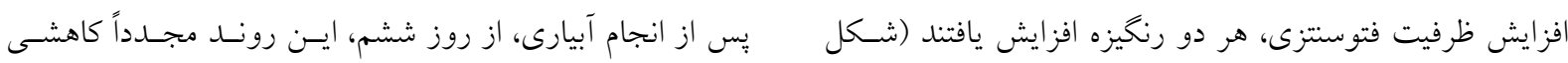

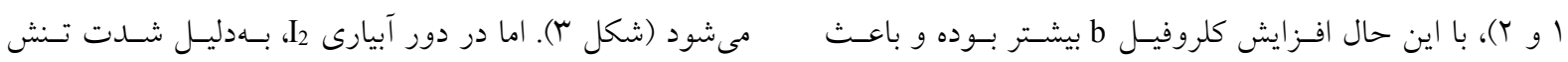




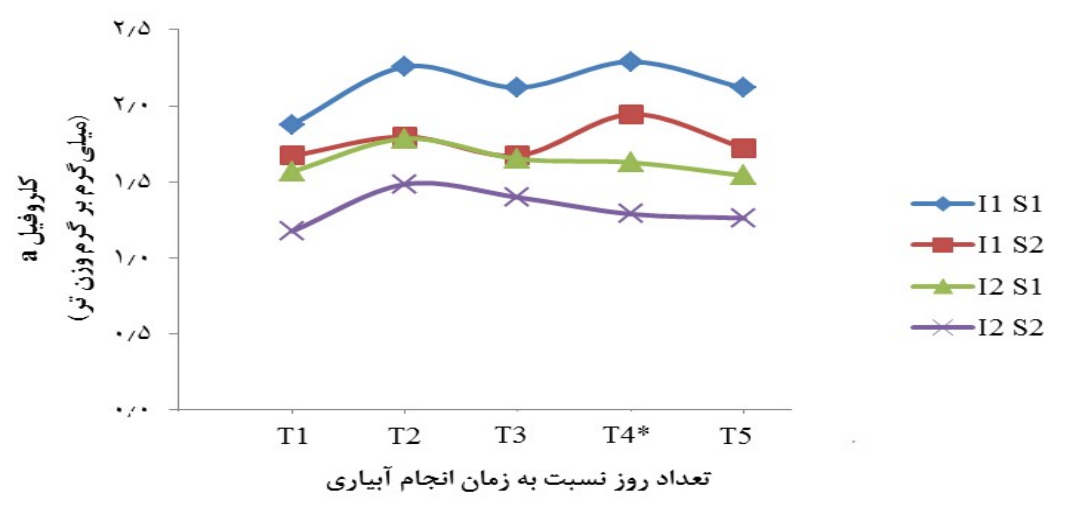

شكل ا. تأثير برهمكنش دور آبيارى، زمان و سيدروفور بر ميزان كلروفيل a برى ذرت دانهاى." براى دور آبيارى VD ميلىمتر، آبيارى

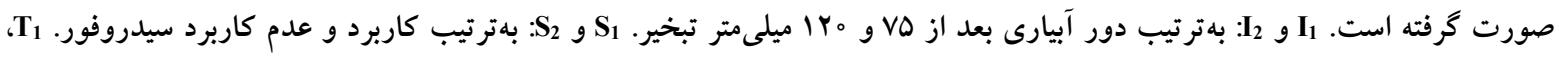


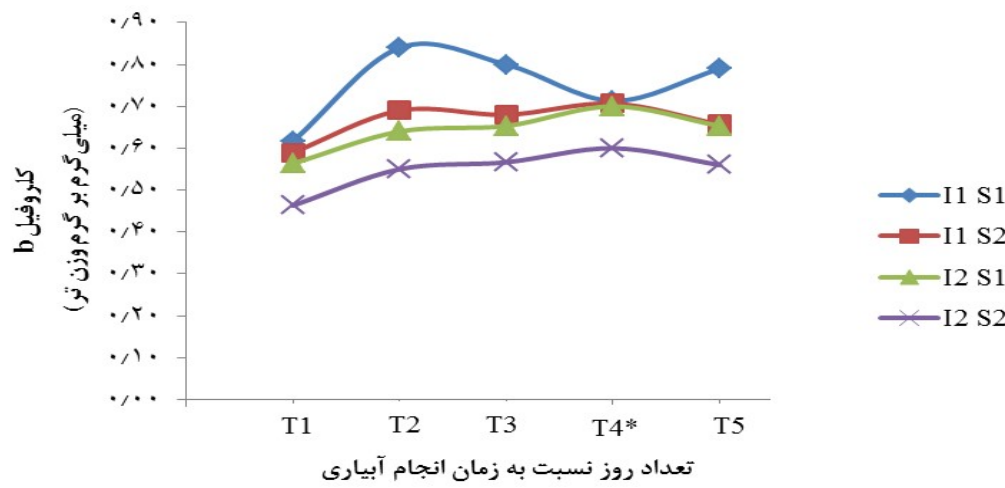

شكل r. تأثير برهمكنش دور آبيارى، زمان و سيدروفور بر ميزان كلروفيل b برى ذرت دانهاى." براى دور آبيارى VD ميلىمتر، آبيارى

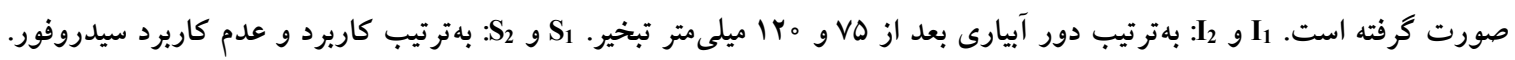
作

ينجم پِ از آبيارى روند تغييرات نزولى اسـت. امـا در فاصسله

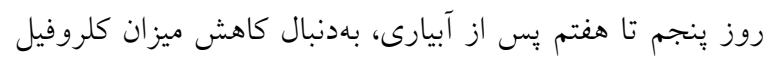

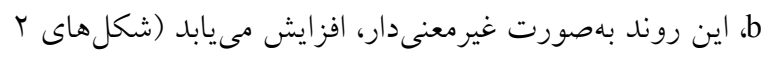

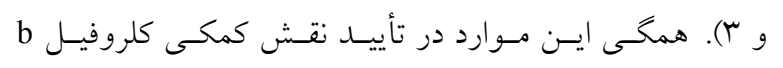

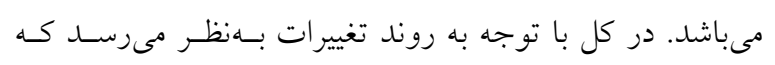

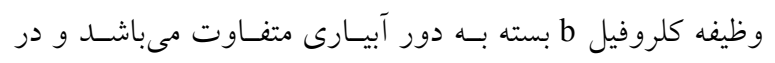

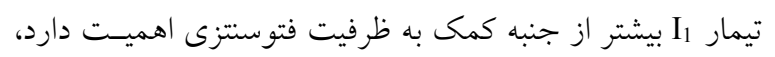

وارده بيشتر، اين نسبت كمتر از دور آبيارى II مىباشـــ بعسد از

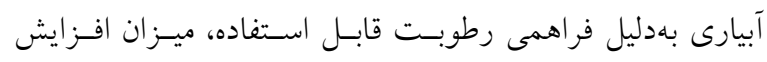

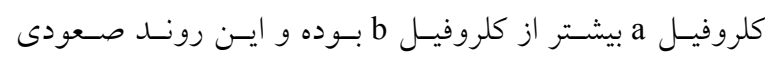

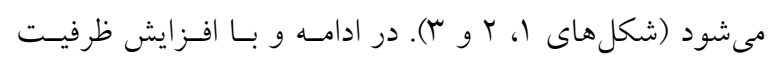

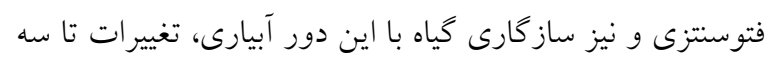

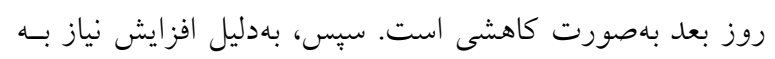

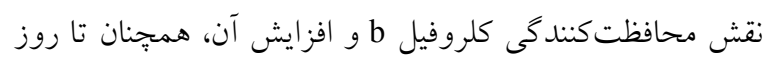




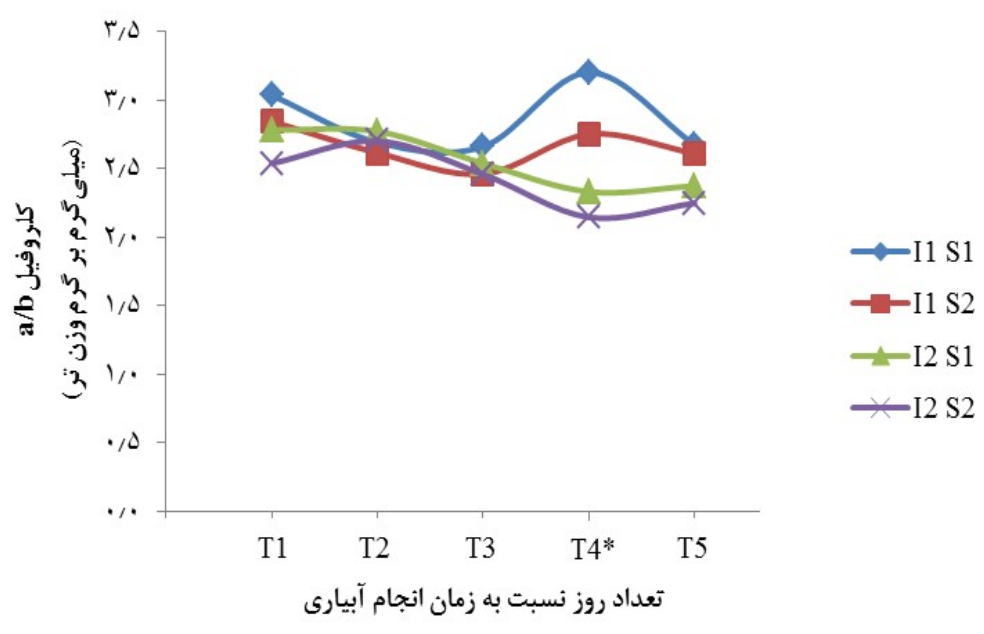

شكل r. تأثير برهمكنش دور آبيارى، زمان و سيدروفور بر ميزان كلروفيل a/b برى ذرت دانهاى." براى دور آبيارى VD ميلىمتر، آبيارى

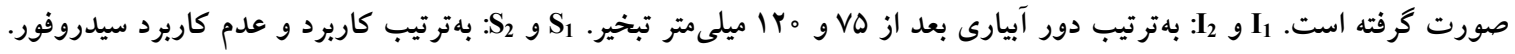


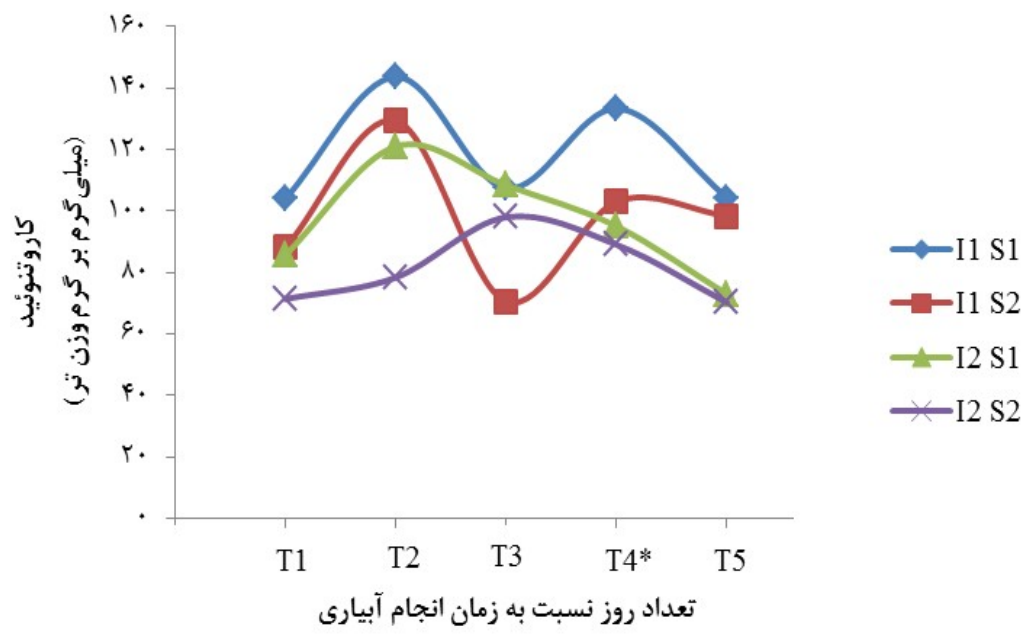

شكل F. تأثير برهمكنش دور آبيارى، زمان و سيدروفور بر ميزان كارتنوئيد برى ذرت دانهاى. " براى دور آبيارى VD ميلىمتر، آبيارى

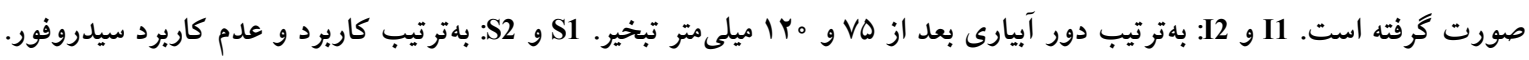

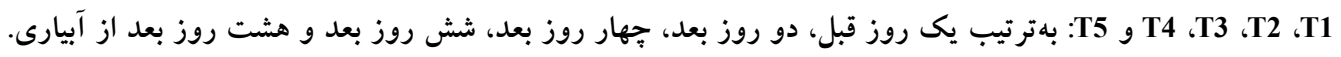

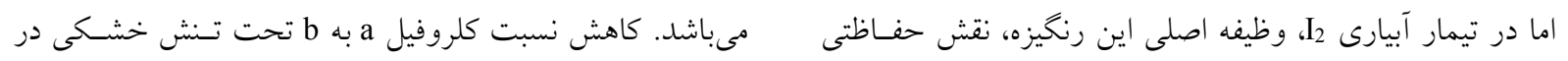

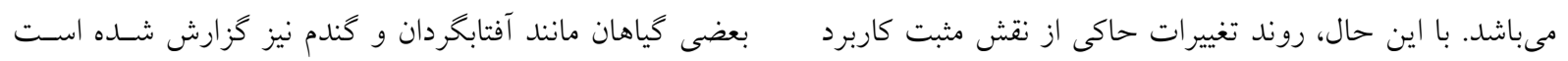

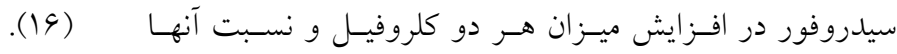


اسـتفاده در خــاك، ارتبــاط داشـته و در دور آبيـارى Iال، مقــدار

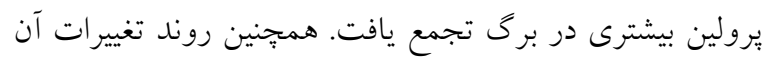

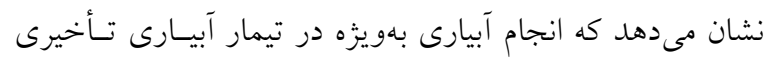

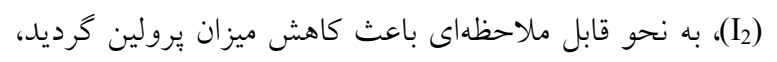

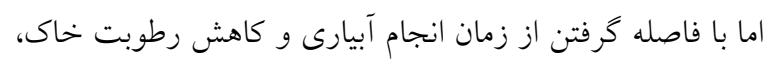

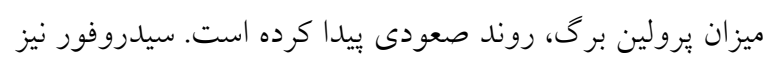

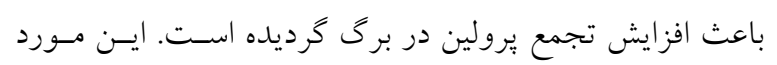

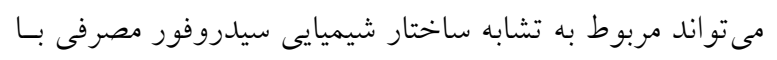

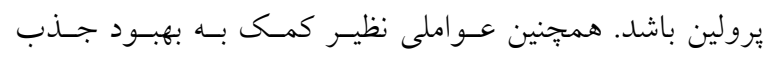

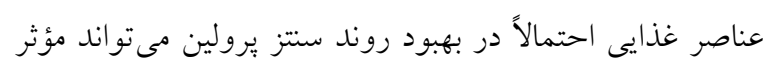
بوده باشد.

\section{قندهاى محلول برى}

اثر اصلى عوامل آزمايشى و نيز برهمكنش دو جانبه دور بآبيارى

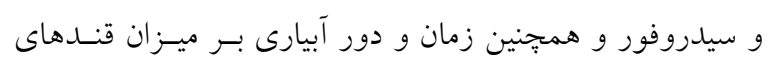

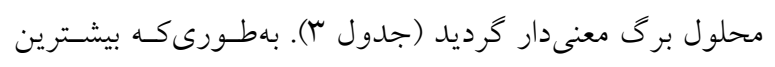

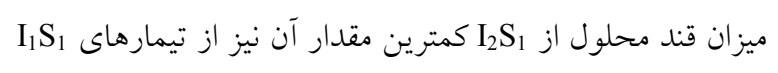

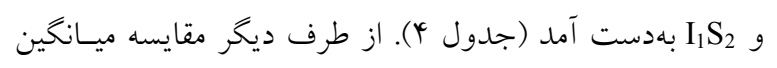

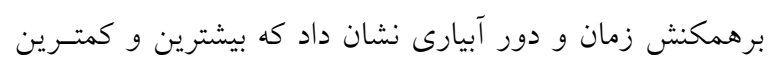

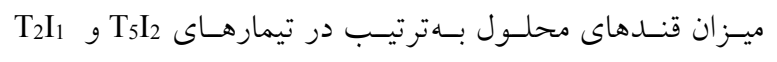

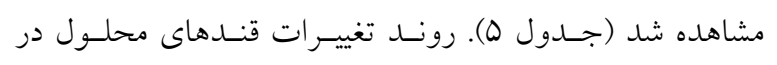
مراحل مختلف نمونهبردارى در سطوح مختلف آبيارى نيز نشان

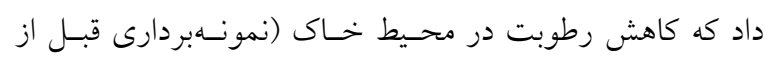

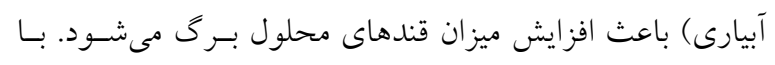

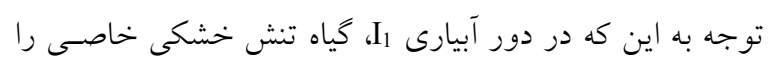
تحمل نمى كند، تغييرات قندهاى محلول برى، مختصر مى دياشد.

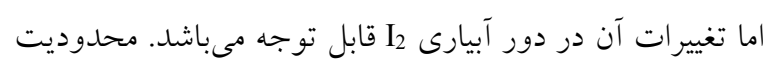

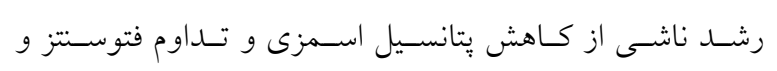

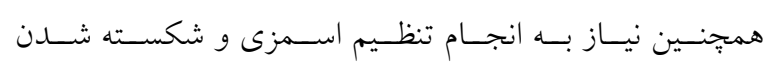

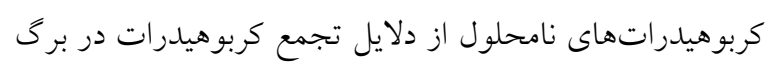
مىباشد. انجام آبيارى و فراهمى رطوبت دريل در خاك، زمينه شروع

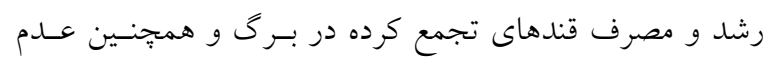

كارتنوئيدها بهعنوان رنخيزههـاى كيرنسـده (آنستن) يرتوهـاى

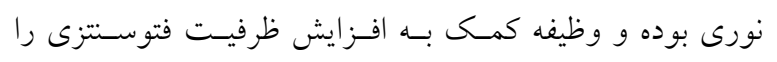

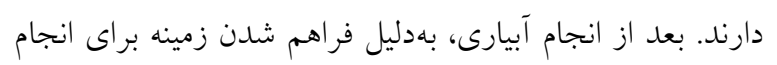

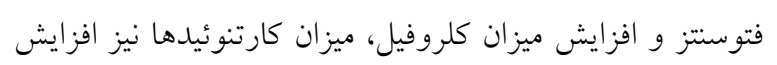

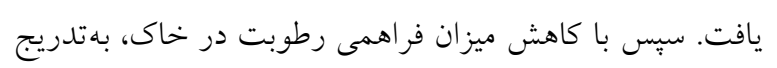

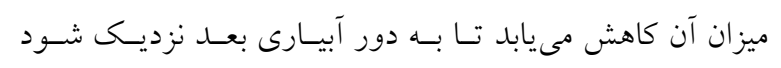

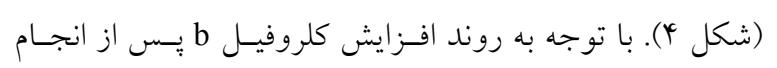

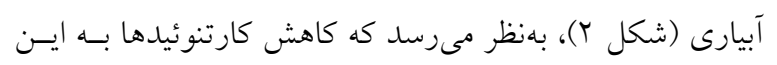

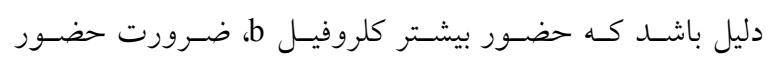
كارتنوئيدها را كاهش داده است.

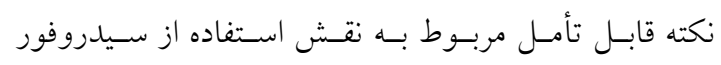

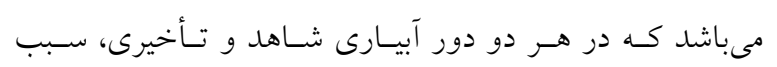

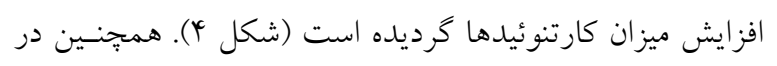

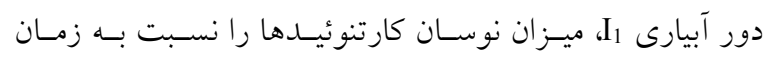

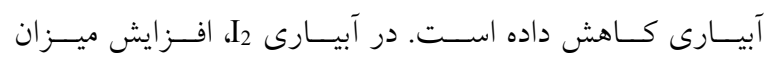

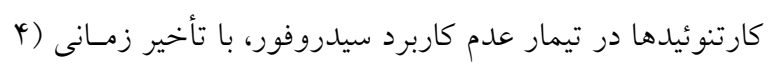

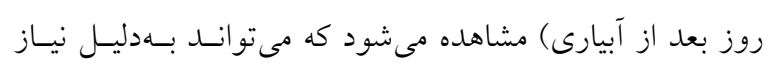

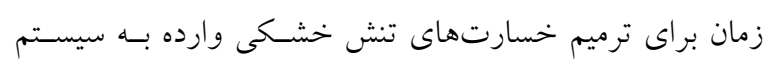

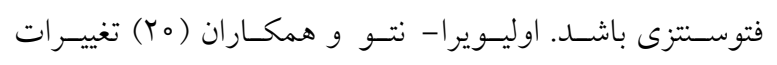
متابوليكى را عامل كاهش سطوح رنخيزههاى فتوسـنتزى دركيـاه

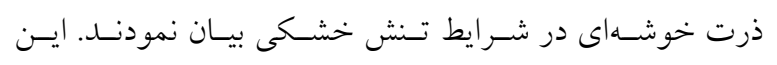

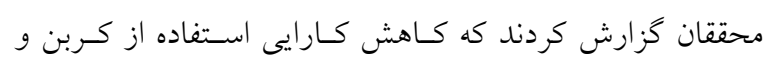
افزايش توليد اتانول و لاكتات سبب كـاهش سـتنز كارتنوئيسدها مىشود. يرولين برى أن إن

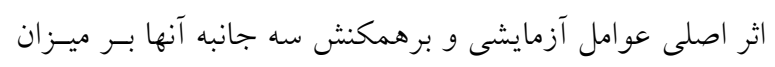

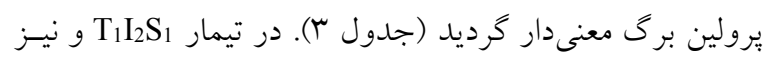
تيمارهاى Tي كمتـرين مقـدار يـرولين نيـز از تيمـار

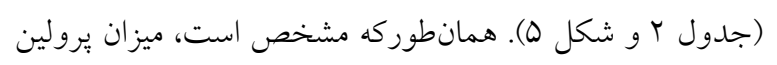

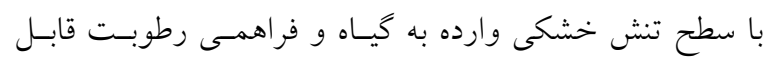


روند تغييرات صفات فيز يولوزيك ذرت متأثر از آبيارى تأخيرى و ...

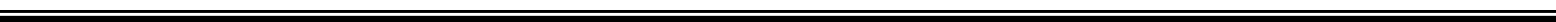

جدول r. تجزيه واريانس صفات غلظت بِرولين، قند محلول، ساكارز و مالون دى آلدئيد برى - اعداد ميانخين مربعات مىباشد.

\begin{tabular}{|c|c|c|c|c|c|}
\hline مالون دى آلدئيد & ساكارز & قندهاى محلول & يرولين & درجه آزادى & منابع تغيير \\
\hline 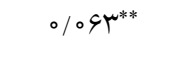 & $\circ / 0 \mid \Gamma^{* *}$ & $\circ / \wedge \Delta Y^{* *}$ & IV/RT:** & r & بلوك \\
\hline$r / 4||^{* *}$ & $\circ /$ YG H** $^{* *}$ & $r Q / \Gamma^{* * *}$ & $M I V^{* *}$ & 1 & دور آبيارى (I) \\
\hline $0 / K Y G^{* *}$ & $\circ / \circ \Lambda^{* *}$ & $\left.9 / Y_{0}\right)^{* *}$ & rYq/T*** & 1 & سيدروفور (S) \\
\hline$\circ / \mu_{\circ} *$ & $\circ / 011^{* *}$ & $r / \circ Y^{*}$ & $91 / 0 r^{* *}$ & 1 & $\mathrm{I} \times \mathrm{S}$ \\
\hline O/OOY & \%/Oör &.$/ 1 O F$ & $r / N 10$ & 9 & خطاى a \\
\hline • & $\circ / \circ \nvdash \varphi^{* *}$ & $r / 911^{* *}$ & $\| \Lambda / \wedge^{* *}$ & r & زمان (T) \\
\hline ס/०rY** & $\circ / \circ \circ Q^{* *}$ & $\circ / \Lambda ૬ 9^{* *}$ & $r \Delta / \Delta r^{* *}$ & r & $\mathrm{T} \times \mathrm{I}$ \\
\hline$\circ / \circ Y^{* *}$ & $\circ / 001^{*}$ & $\circ / \circ 99^{n s}$ & V/NFyns & r & $\mathrm{T} \times \mathrm{S}$ \\
\hline $0 / 01 r^{* *}$ & $\circ /\left.\circ \circ\right|^{\mathrm{ns}}$ &.$/ 09 Q^{\mathrm{ns}}$ & $11 / r \wedge^{*}$ & r & $\mathrm{T} \times \mathrm{I} \times \mathrm{S}$ \\
\hline $0 / 001$ & $\circ / 0000$ & $0 / 0 k y$ & 吾 & re & خطاى bط \\
\hline $9 / \pi$ & $V / 9$ & $9 / V$ & $10 / \mathrm{V}$ & & ضريب تغييرات (\%) \\
\hline
\end{tabular}

جدول ٪ا. مقايسه ميانكين اثرات متقابل دور آبيارى × سيدروفور بر غلظت قندهاى محلول و ساكارز برك ذرت دانهاى

\begin{tabular}{|c|c|c|c|c|c|}
\hline ساكارز & \multicolumn{3}{|c|}{ قندهاى محلول } & \multirow{2}{*}{ سيدروفو } & \multirow{2}{*}{ دور آبيارى } \\
\hline \multicolumn{4}{|c|}{$\mathrm{mg} / \mathrm{g} \mathrm{FW}$} & & \\
\hline.$/ 490$ & $\mathrm{c}$ & $r / 910$ & $\mathrm{c}$ & $\mathrm{S}_{1}$ & $\mathrm{I}_{1}$ \\
\hline $0 / Y 19$ & d & $r / M Y I$ & $\mathrm{c}$ & $\mathrm{S}_{2}$ & \\
\hline - KYO & $\mathrm{a}$ & F/TAY & $\mathrm{a}$ & $\mathrm{S}_{1}$ & $\mathrm{I}_{2}$ \\
\hline $0 / M Y I$ & $\mathrm{~b}$ & $r / T V Y$ & $\mathrm{~b}$ & $\mathrm{~S}_{2}$ & \\
\hline.$\% 1 \mathrm{~V}$ & & $\circ / \pi \Delta$ & & & LSD5\% \\
\hline
\end{tabular}

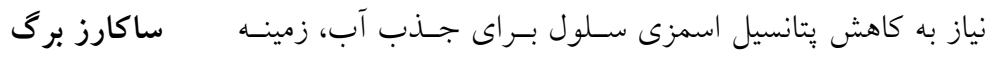

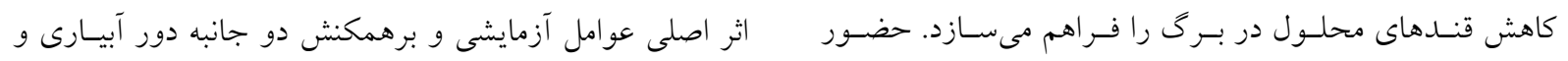

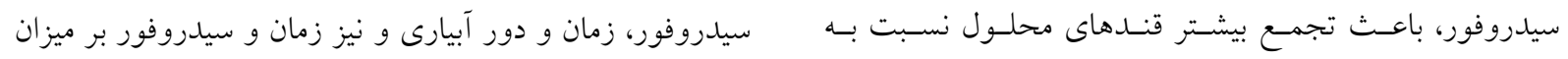

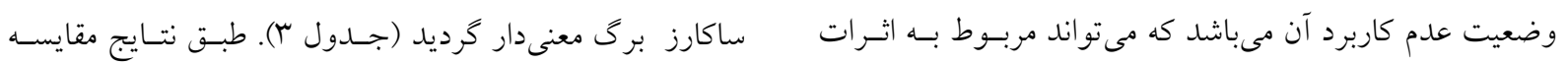

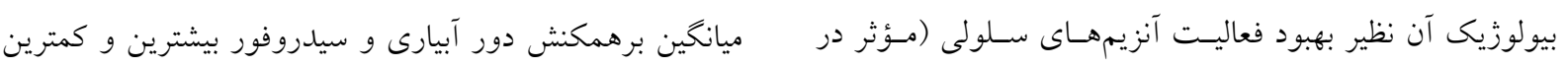

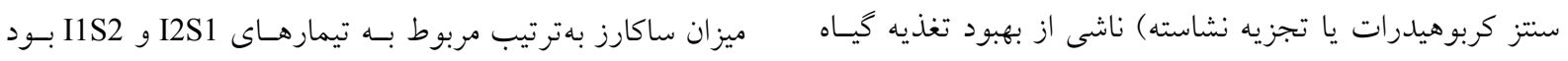

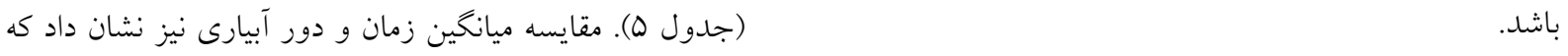

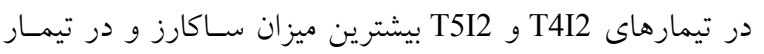




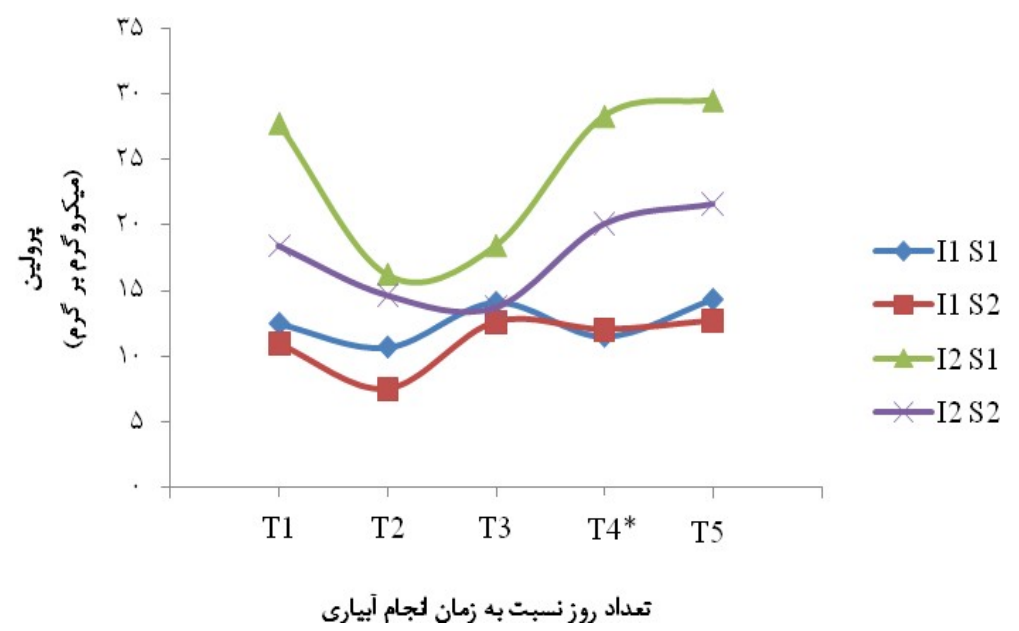

شكل ه. تأثير برهمكنش دور آبيارى، زمان و سيدروفور بر ميزان يرولين برى ذرت دانهاى." براى دور آبيارى VD ميلىمتر آبيارى صورت

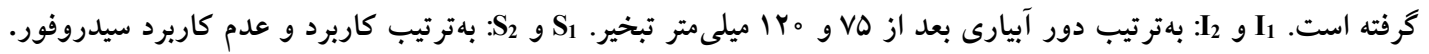
位

\section{مالون دى آلدئيد برى (MDA)}

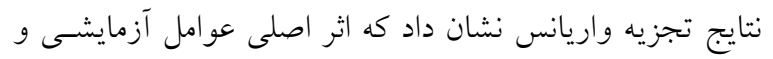

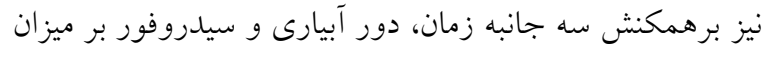

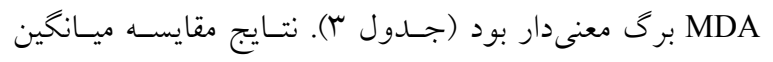
بـرهمكنش زمـان، دور آبيـارى و سـيدروفور نشـان داد كـه در

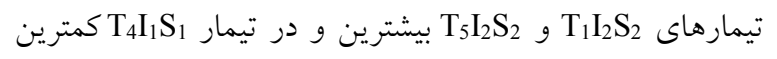

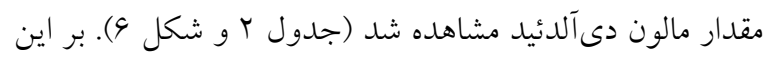
اساس مىتوان كفت كه سطح MDA در مجموع در دور آبيارى

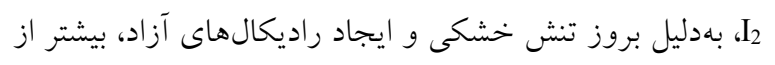

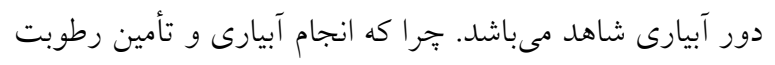

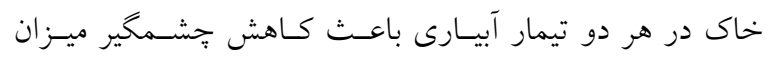

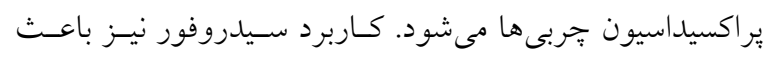

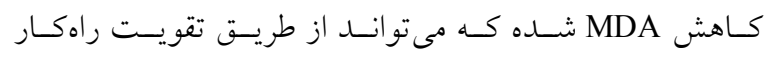

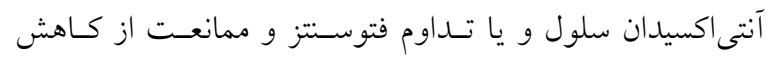

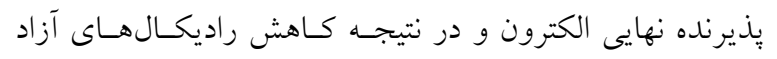

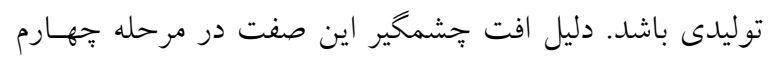

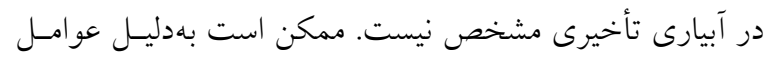

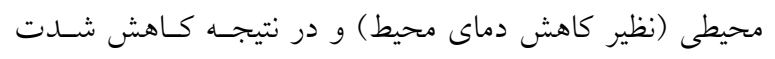

T2I1 كمترين ميزان سـاكارز مشـاهده شــ (جــدول 9). نتـايج حاصل از مقايسه ميانخين بـرهمكنش زمـان و سـيدروفور نيـز نشان داد كه درتيمار T3S1 و T5S1 بيشترين ميزان سـاكاروز و

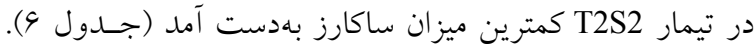

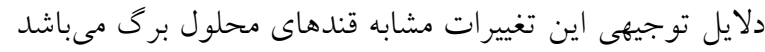

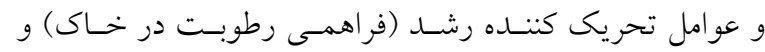

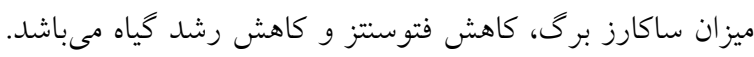

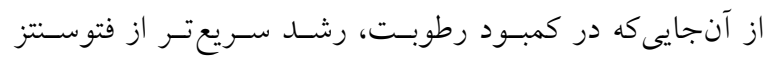

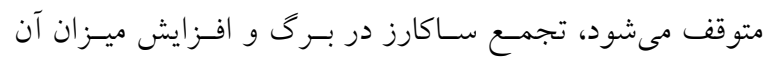

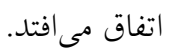
برخى از محققان دريافتند كه تنش خشـكى سـبب افـزايش

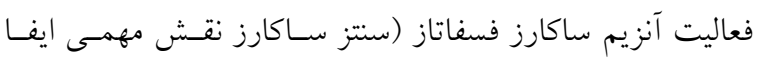
مى كند) در كياه سيبزمينى شده است. همجنين تسنش خشكى

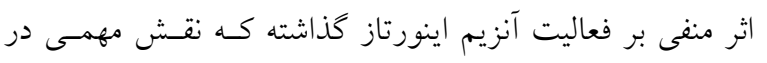

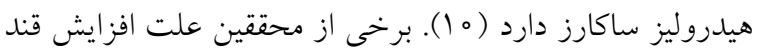
محلول و ساكارز بـا افـزايش تــش خشكى را كـاهش ميـزان فتوسنتز، تبديل نشاسته به قند و يا مصرف كمتسر كربوهيــدرات توسط كياه در شر ايط خشكى مى دانند (r)). 
روند تغييرات صفات فيز يولوزيك ذرت متأثر از آبيارى تأخيرى و ...

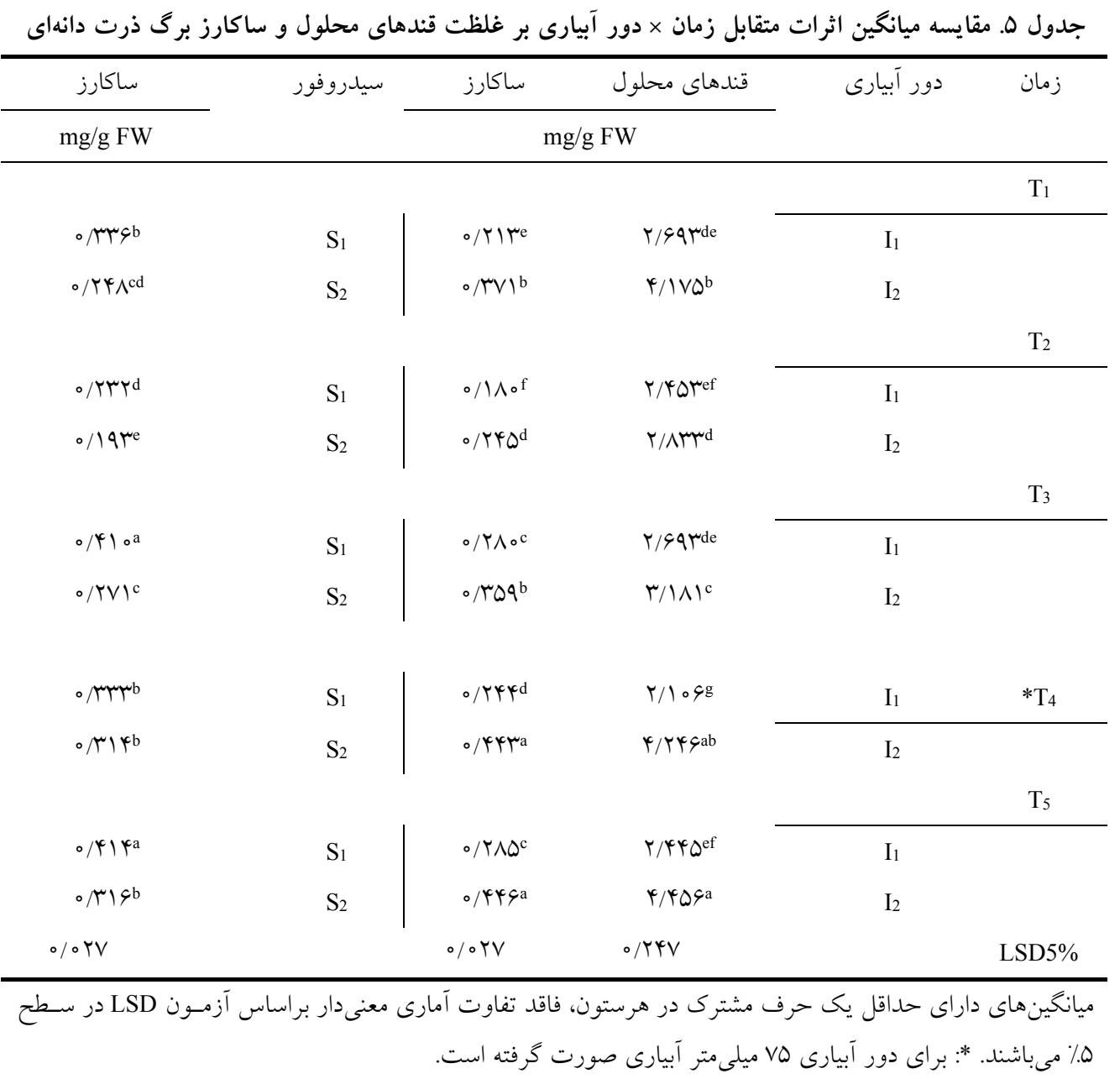

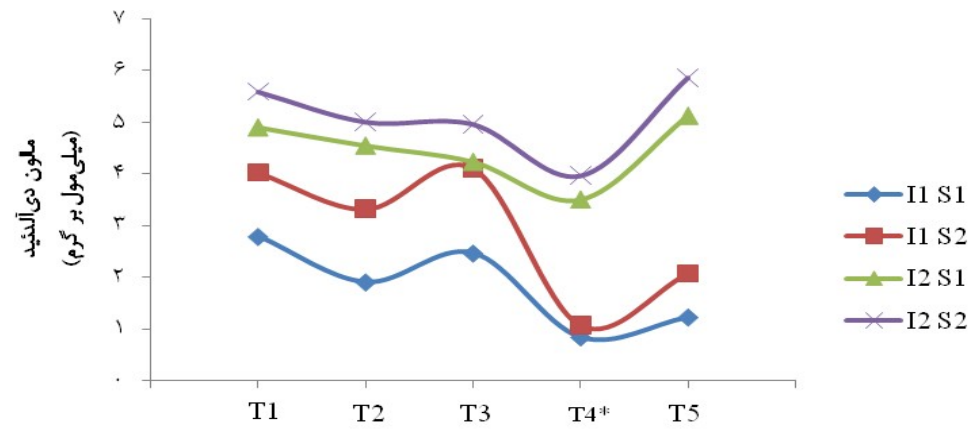

تعداد روز نسبت بد زمان الجام آبيارى

شكل 9. تأثير برهمكنش زمان، دور آبيارى و سيدروفور بر ميزان مالون دى آلدئيد برى ذرت دانهاى. " براى دور آبيارى VD ميلىمتر آبيارى

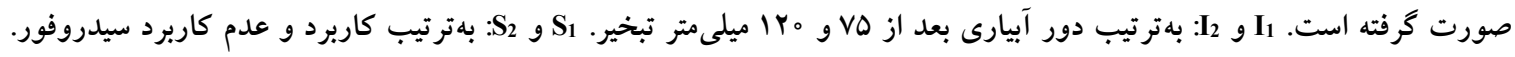
位 


$$
\begin{aligned}
& \text { تنش خشكى وارده باشد. كمبود آب، با توليسـ كونـههاى فعـال و خسارات وارده به سيستم غشائى سلول همـراه بــود. كـاربرد }
\end{aligned}
$$

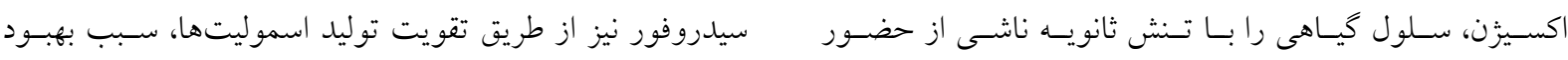

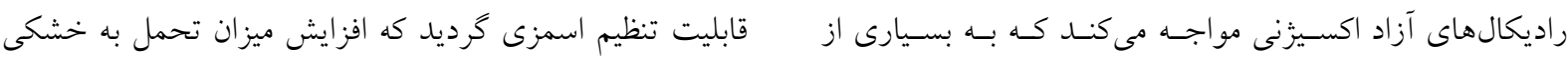

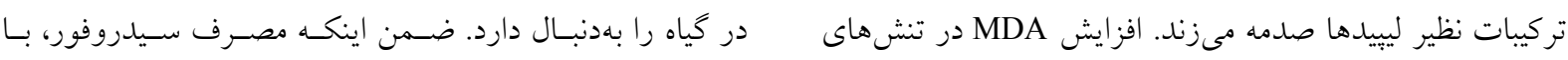

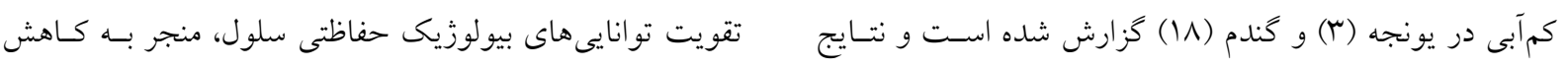

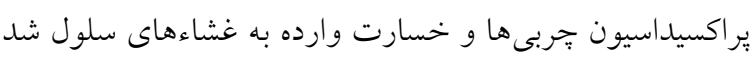

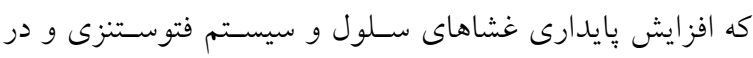

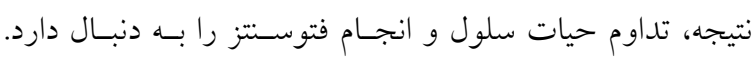

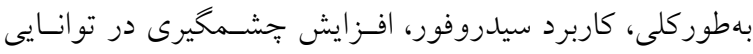

$$
\begin{aligned}
& \text { تنظيم اسمزى سلول و تحمل به خشكى كياه را بههمر اه داشت. } \\
& \text { اين تحقيق را تكميل مى كند. } \\
& \text { نتيجه گيرى } \\
& \text { تاخير در آبيارى و بروز تنش خشكى، بـا كـاهش رنخيـزههـاى }
\end{aligned}
$$

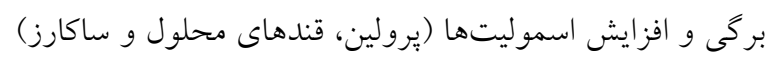

\section{منابع مورد استفاده}

1. Anonymous. 2015. Statistical yearbook of Iran ministry of jihad-e-agriculture. Available online at: http://agrijahad.ir/Portal/Home/Default.aspx?CategoryID=95a8e7d0-e5f0-4f2d-a241-792106c74dcc. Accessed 1 January 2017.

2. Ahmad, P. and S. Sharma. 2010. Physio-biochemical attributes in two cultivars of mulberry (Morus alba L.) under $\mathrm{NaHCO}_{3}$ stress. International Journal of Plant Production 4: 79-86.

3. Antolín, M. C., I. Muro and M. Sánchez-Díaz. 2010. Application of sewage sludge improves growth, photosynthesis and antioxidant activities of nodulated alfalfa plants under drought conditions. Environmental and Experimental Botany 68: 75-82.

4. Apel, K. and H. Hirt. 2004. Reactive oxygen species: metabolism, oxidative stress, and signal transduction. Annual Review of Plant Biology 55: 373-399.

5. Arnon, A. N. 1967. Method of extraction of chlorophyll in the plants. Agronomy Journal 23: 112-121.

6. Bates, L. S., R. D. Waldren and I. D. Teare. 1973. Rapid determination of free proline for water stress studies. Plant and Soil 39: 205-207.

7. De Vos, C. H. and H. Schat. 1991. Increased resistance to copper-induced damage of the root plasma membrane in copper tolerant Silene cucubalus. Physiologiae Plantarum 82: 523-528.

8. Edmeades, G. O., J. Bolanos, H. R. Lafitte, S. Rajaram, W. Pfeiffer and R. A. Fischer. 1989. Traditional approaches to breeding for drought Resistance in Cereals. pp. 27-52 In: F. W. G. Baker (Ed.), Drought Resistance in Cereals.

ICSU, Paris and C. A. B. International, Wallingford, England.

9. Fuentes-Ramirez, L. E. and J. Caballero-Mellado. 2006. Bacterial biofertilizers. pp. 143- 172. In: Z. A. Siddiqui (Ed.). PGPR: Biocontrol and Biofertilization. Springer, Netherlands.

10. Geigenberger, P., R. Reimholz, M. Geiger, L. Merlo, V. Canale and M. Stitt. 1997. Regulation of sucrose and starch metabolism in potato tubers in response to short-term water deficit. Planta 201 (4): 502-518.

11. Irigoyen, J. J., D. W. Emerich and M. Sanchez Diaz. 1992. Water stress induced changes in concentrations of proline and total soluble sugars in nodulated alfalfa (Medicago sativa) plants. Plant Physiolgy 84: 55-60.

12. Justyna, P. G. and K. Ewa. 2013. Induction of resistance against pathogens by $\beta$-aminobutyric acid. Acta Physiologiae Plantarum 35: 1735-1748.

13. Karimi, H. R., Z. Zamani, A. Ebadi and R. Fatahi. 2011. Effects of water salinity on growth indices and physiological parameters in some pistachio rootstocks. Journal of Plant Nutrition 34: 935-944.

14. Khajepur, M. 2013. Cereals. Publications of Isfahan Agricaltural Jihad. Isfahan.

15. Kuchaki, A. and A. Alizadeh. 1986. Principle of Agriculture in Dry Regions. Astan-e Qods-e Razavi Press. Mashhad.

16. Kukavica, B. and S. V. Jovanovic. 2004. Senescence-related changes in the antioxidant status of ginkgo and birch leaves during autumn yellowing. Physiologiae Plantarum 122 (3): 321- 327.

17. Mittler, R. 2002. Oxidative stress, antioxidants and stress tolerance. Trends in Plant Science 7: 405-410. 
18. Moaveni, P. 2011. Effect of water deficit stress on some physiological traits of wheat (Triticum aestivum) Agricultural Science Research Journal 1(1): 64 - 68.

19. Naghashzadeh, M. R., H. Heidari Sharifabad, E. Majidi Heravan, M. Rafiee, F. Rejali and N. Imantalab. 2014. Evaluation of maize leaf gas exchanges with application of mycorrhizal biofertilizer under drought stress conditions. Seed and Plant Production Journal 30-2 (1): 47-59.

20. Oliviera-Neto, C. F., A. K. Silva-Lobato, M. C. Goncalves-Vidigal, R. C. L. Costa, B. G. Santos Filho, G. A. R. Alves, W. J. M. Silva-Maia, F. J. R. Cruz, H. K. B. Neres and M. J. Santos Lopes. 2009. Carbon compounds and chlorophyll contents in sorghum submitted to water deficit during three growth stages. Journal of Food, Agriculture and Environment 7: 588-593.

21. Sharma, A. and B. N. Johri. 2003. Growth promoting influence of siderophore-producing Pseudomonas strains GRP3A and PRS9 in maize (Zea mays L.) under iron limiting conditions. Microbiological Research 158: $243-248$.

22. Sharma, S., N. Grandvaux, G. P. Zhou, R. Lin and J. Hiscott. 2003. Triggering the interferon antiviral response through an IKK-related pathway. Science 300: 1148-1151.

23. Tahmasbi, F., A. Lakzian, K. Khavazi and A. Pakdin Parizi. 2014. Isolation, identification and evaluation of sidrophore production in Pseudomonas bacteria and its effect on hydroponically grown corn. Journal of Cellular and Molecular Researches 27 (1): 75-86. (In Farsi)

24. Tambussi, E. A., C. G. Bartoli, J. Bettran, J. J. Guiamet and J. C. Araus. 2000. Oxidative damage to thylakoids proteins in water stressed leaves of wheat (Triticum aestivum L.). Plant Physiology 108: 398-404.

25. Van Handel, E. 1968. Direct microdetermination of sucrose. Analytical Biochemistry 22 (2): 280-283. 


\title{
Modification of Physiological Characteristics in Maize as Influenced by Delayed Irrigation and Bacterial Siderophore
}

\author{
S. Sarrafi ${ }^{1}$, A. Azari ${ }^{\star 2}$, R. Saberi Riseh ${ }^{3}$ and A. A. Mohammadi Mirik ${ }^{2}$
}

(Received: October 8-2016; Accepted: February 22-2017)

\begin{abstract}
To study the effect of bacterial siderophore on the second crop of maize (SC645) under drought stress conditions, a splitfactorial experiment, arranged in a randomized complete block design with three replications was conducted in Faculty of Agriculture, Vali-e-Asr University of Rafsanjan at summer 2014. Sampling time was considered as main factor. Five samplings were performed after imposing the irrigation treatments. The factorial combination of two irrigation intervals (75 (unstressed control) and $120 \mathrm{~mm}$ evaporation from Class-A pan) and two siderophore application treatments (with and without application) were considered as sub factors. The foliar application of siderophore $\left(2000 \mathrm{mg} \mathrm{l}^{-1}\right)$ was applied two times. In addition, $20 \mathrm{~kg}$ siderophore $\mathrm{ha}^{-1}$ was applied with irrigation. The $\mathrm{chl} \mathrm{a}, \mathrm{b}$ and carotenoids decreased with delay in irrigation while increased with siderophore application in each irrigation. Also, proline, soluble sugars and sucrose accumulated with increasing irrigation intervals and delay in irrigation. Increase in intervals and delay in irrigation without siderophore application resulted in an increase in membrane lipid peroxidation. The trend of changes in traits was significantly influenced by the availability of soil moisture, and modifications in the above-mentioned trait values were observed with delays in irrigation. Irrigating (rewatering) of plants subjected to water deficit stress did not improve their traits values compared with the unstressed control, indicating that short-term effects of drought would not recover by irrigation. Bacterial siderophore enhances the ability of osmotic adjustment and photosynthetic capacity and is effective in ameliorating the harmful effects of drought.
\end{abstract}

Keywords: Delayed irrigation, Maize, Osmotic adjustment, Siderophore

1, 2. MSc. Student and Assistant Professors, Respectively, Department of Agronomy and Plant Breeding, Faculty of Agriculture, Vali-e-Asr University of Rafsanjan, Rafsanjan, Iran.

3. Associate Professor, Department of Plant Protection, Faculty of Agriculture, Vali-e-Asr University of Rafsanjan, Rafsanjan, Iran.

*. Corresponding Author, Email: armanazari@vru.ac.ir 